\title{
El rostro de Dios en la poesía de Blas de Otero y Yehuda Amijai
}

\author{
José Alberto GariJo SERRANO \\ Pontificia Universidad Gregoriana \\ joagarijo@gmail.com
}

\section{RESUMEN}

Blas de Otero (1916-1979) y Yehuda Amijai (1924-2000) dan la palabra en su poesía al ser humano del siglo XX y a las cuestiones de su existencia: el amor, la soledad, el sufrimiento, la solidaridad, la injusticia, la muerte, la esperanza. Un lugar central de su obra lo ocupa el Dios misericordioso y fiel de la Biblia, cuya imagen parece desmentir la dramática situación en que el ser humano a veces vive. Frente a la Palabra de Dios se levanta la palabra del poeta con su arsenal de recursos: la intertextualidad, la metáfora, la comparación, la antítesis, los efectos sonoros, la ironía. Ambos autores sitúan al lector ante la tarea de deconstruir y reconstruir el rostro del Dios de la Biblia.

Palabras clave: Blas de Otero, Yehuda Amijai, Dios, poesía desarraigada, poesía israelí, poesía existencial.

\author{
The depiction of God in the poetry \\ of Blas de Otero and Yehuda Amichai
}

\begin{abstract}
The poetry of Blas de Otero (1961) and Yehuda Amichai (1924-2000) invites the 20th century human being to speak out on the main issues of his existence: love, loneliness, suffering, solidarity, injustice, death, hope. A central place in their work is taken up by the merciful and faithful God of the Bible, whose image seems to be refuted by the dramatic situation in which the human being happens to live. The poet's word stands up against God's word equipped with his resources: intertextuality, metaphor, comparison, antithesis, sound effects, irony. Both authors place the reader before the task of construct and deconstruct the depiction of the Biblical God.
\end{abstract}

Keywords: Blas de Otero, Yehuda Amichai, God, uprooted poetry, Israeli poetry, existencial poetry.

SUMARIO: 1. Blas de Otero. 1.1. La imagen de Dios en la poesía del periodo de formación (1935-1950). 1.2. La imagen de Dios en la etapa existencial o de «poesía desarraigada» (1950-1955). 1.3. La imagen de Dios en la etapa social o histórica (1955-1964). 2. Yehuda Amijai. 2.1. Vida. 2.2. Carácter de la poesía de Yehuda Amijai. 2.3. Dios en la poesía de 1948-1962. 2.4. Dios en la poesía de 1962-1968: «Viajes del último Benjamín de Tudela». 2.5. Dios en la última poesía de Amijai. 3. Conclusión. 
El español Blas de Otero (1916-1979) y el israelí Yehuda Amijai (1924-2000), afincados respectivamente en los extremos occidental y oriental del Mediterráneo, son testigos privilegiados de la evolución estética de la poesía de sus respectivas lenguas en el siglo Xx. A pesar de su distancia cultural y geográfica, sus obras poéticas ven la luz casi simultáneamente y responden a preocupaciones muy similares. Blas de Otero publica lo que considera su primera obra, Angel fieramente humano, en 1950, y Amijai da a la luz pública su primer libro, Ahora y en otros dias (עכשיו ובימים (אחרים), en 1955. Las sociedades respectivas y Europa en su conjunto afrontan en ese momento la recuperación moral de sus posguerras particulares, que se presenta más difícil que la recuperación material. La literatura, después de haber asimilado las vanguardias en la época de entreguerras, toma ahora un cariz existencialista, se vuelve hacia el ser humano concreto y afronta la problemática de su vacío interior, su soledad y su impotencia.

Esta poesía existencialista, que se vuelve hacia el ser humano concreto, no idealizado, que escudriña en su interior para poner palabra, ritmo y rima a lo inexpresable, necesariamente afronta el tema de Dios. De él se espera una respuesta a tantas preguntas que el hombre se plantea. Molesta su silencio, su indiferencia, incluso su aparente complacencia ante el sufrimiento de los humanos. El Dios a quien se interpela en esta poesía es el Dios de la Biblia, «Dios de Abraham, de Isaac y de Jacob, no de los filósofos y de los sabios», como diría Pascal en su Memorial. Es el Dios que dice haberse comunicado con el hombre y ahora calla, que dice ser su salvación, y que ahora está indiferente al ser humano.

Afrontaremos el estudio de estos dos poetas con una breve presentación de su biografía y su obra y un comentario a algunos de sus poemas en los que aparece más clara esta problemática del Dios de la Biblia.

\section{BLAS DE OTERO}

Blas de Otero Muñoz (1916-1979) nace en Bilbao. Su primera juventud estará marcada por la espiritualidad ignaciana. En 1926 la familia se traslada a Madrid. La muerte del padre acentúa la ruina de la familia y, aunque en 1931 inicia estudios de Derecho, debe abandonarlos para volver a Bilbao, haciéndose cargo de la familia. Empieza a publicar su poesía muy marcada por los místicos españoles, Juan Ramón Jiménez y los poetas del 27. Tras la Guerra Civil intenta con dificultad combinar su vocación artística con los estudios de Derecho en Zaragoza, Madrid y Bilbao. En 1950 conoce a la poeta y actriz Tachia Quintanar, quien será su compañera durante muchos años de su vida. Blas de Otero, que en 1952 se había afiliado al Partido Comunista, se autoexilia en París por unos años, aunque vuelve en 1955. De 1956 a 1959 vive en Barcelona. En 1959 gana el Premio de la Crítica por Ancia y en 1962 el Premio Fastenrath. En 1964 se casa en Cuba con Yolanda Pina, de la que se divorcia en 1967. Mantiene una militancia activa a favor de la restauración democrática en España. Muere el 29 de junio de 1979 en Majadahonda (Madrid) de una embolia pulmonar. 


\subsection{LA IMAGEN DE DIOS EN LA POESÍA DEL PERIODO DE FORMACIÓN (1935-1950)}

La obra representativa de este periodo es Cántico espiritual (1942), rememorando a san Juan de la Cruz. Es una poesía de corte místico que busca la ascensión del hombre en la búsqueda de Dios. Un ejemplo es este soneto que da inicio a Cántico espiritual, en el que se aprecia la influencia de los místicos castellanos -la «herida del amor» tan presente en la poesía castellana desde el Cancionero, el anhelo de lo divino, la dulzura del encuentro con el Amado y el dolor de la ausencia-, llenos del sosiego de la religiosidad juvenil, pero en el que destaca ya con fuerza el Yo del poeta que interpela directamente a Dios, y que será frecuente en la etapa existencialista ${ }^{1}$ :

Todo el amor divino, con el amor humano, me tiembla en el costado, seguro como flecha.

La flecha vino pura, dulcísima y derecha: el blanco estaba abierto, redondo y muy cercano.

Al presentir el golpe de Dios, llevé la mano, con gesto doloroso, hacia la abierta brecha. Mas nunca, aunque doliéndose, la tierra le desecha al sembrador, la herida donde encerrar el grano.

¡Oh Sembrador del ansia; oh Sembrador de anhelo, que nos duele y es dulce, que adolece y nos cura! Aquí tenéis, en haza de horizontes, mi suelo para la vid hermosa, para la espiga pura. El surco es como un árbol donde tender el vuelo, con ramas infinitas, doliéndose de altura

\subsection{LA IMAGEN DE DIOS EN LA ETAPA EXISTENCIAL O DE «POESÍA DESARRAIGADA» (1950-1955)}

En España, en la época que Ricardo Gullón llama de la «generación escindida», o de lo que Dámaso Alonso llama «poesía desarraigada», surgen poetas para los que «el mundo nos es un caos y una angustia, y la poesía una frenética búsqueda de ordenación y de ancla» ${ }^{2}$. El verso de Blas de Otero en la etapa de poesía desarraigada es,

\footnotetext{
${ }^{1}$ Cántico espiritual, en Alea 2 (1942). Sobre el carácter místico y existencial de Cántico espiritual cf. L. Urcelay, «Una ruptura en la poesía religiosa de posguerra: el Cantico humano de Blas de Otero»: Cuadernos de la Cultura 2 (1982) pp. 109-129; V. García de la Concha, La poesía española de 1935 a 1975, Madrid, 1987, pp. 539-545.

${ }^{2}$ D. Alonso, «Poesía arraigada y poesía desarraigada», en: Poetas españoles contemporáneos, Biblioteca Románica Hispánica, II. Estudios y ensayos, 6, Madrid, 1965, pp. 349-358; R. Gullón, «La generación de 1936», Asonante 15 (1959) pp. 64-69; Idem., «La generación de 1936», en La invención del 98 y otros ensayos,
} 
como decía Dámaso Alonso, «áspero, no por otra cosa, sino porque se corresponde con el derrumbamiento en huida del mundo y de su imagen del mundo» ${ }^{3}$. En la trayectoria de Blas de Otero esta corriente viene representada por Ángel fieramente humano (1950) y Redoble de conciencia (1951), recogidos y completados con ocho poemas más en Ancia (1958).

\section{a) La temática de Dios, el hombre y el vacio en Ancia}

El enfrentamiento con Dios en Ancia se encuadra en la ruptura con la religiosidad tradicional que sufre Blas de Otero a mediados de la década de los '40. Surge, como él mismo dice, en el poema «Tierra»:

Un hombre como un árbol desgajado.

Una generación desarraigada.

Unos hombres sin más destino que

apuntalar las ruinas ${ }^{4}$.

En ella se dibuja el triángulo hombre - muerte - Dios, que a menudo se simbolizan respectivamente mediante las metáforas árbol-mar-cielo. El hombre aparece como «árbol» (con las raíces metidas en tierra, pero con las ramas levantadas hacia Dios y la eternidad, zarandeado por el viento que lo arranca de la tierra), como en el segundo cuarteto del soneto «Soledad», en el que, en un ingenioso desplazamiento rápido de la metáfora desde el ámbito vegetal al náutico, el hombre es simultáneamente «árbol»y «arboladura»:
Árbol de Dios, oh sí, arboladura
hundida al fondo donde el hombre ama;
y, desde allí, mortal, eterna, clama,
reclama, sueña eternidad y altura.

La muerte, por otro lado, se simboliza como «mar» (amenazador, negro, violento, agitado), y Dios como «cielo» (eternidad, luz), pero a veces también como «mar» (oscuro, violento), tal como expresa, por ejemplo, el poema «Hombre» ${ }^{5}$ :

Luchando, cuerpo a cuerpo, con la muerte,

al borde del abismo estoy clamando

a Dios. Y su silencio, retumbando, ahoga mi voz en el vacío inerte.

Madrid, 1969, pp. 162-177; Cf. V. García de la Concha, op. cit., pp. 539-559; J. Marco, «La poesía», en F. Rico - D. Ynduráin, eds., Historia y crítica de la literatura española. VIII. Época contemporánea (1939-1980), Barcelona, 1980, pp. 109-138.

${ }^{3}$ D. Alonso, «Poetas españoles contemporáneos», en B. de Otero, Ancia, Madrid, 1958, 2003, p. 12; Idem., «Poesía arraigada y poesía desarraigada», p. 350.

${ }^{4}$ B. Otero, op. cit., p. 56.

${ }^{5}$ B. Otero, op. cit., p. 36. 
Oh Dios. Si he de morir, quiero tenerte despierto. Y, noche a noche, no sé cuándo oirás mi voz. Oh Dios. Estoy hablando solo. Arañando sombras para verte.

Alzo la mano, y tú me la cercenas. Abro los ojos, me los sajas vivos. Sed tengo, y sal se vuelven tus arenas.

Esto es ser hombre: horror a manos llenas.

Ser-y no ser- eternos, fugitivos.

¡Ángel con grandes alas de cadenas!

La voz del poeta se hace grito desgarrado desde lo hondo de su condición mortal y solitaria. Es la del ser humano que se sabe creación de Dios, pero abocado a la muerte, y que le pide cuentas a su Creador de por qué lo ha creado mortal. El «ser -y no ser- eternos, fugitivos», con resonancias shakesperianas. La muerte es el «abismo» que se presenta delante del poeta, y ante el cual grita y grita, «noche a noche». Pero no hay respuesta. Dios no responde. Esta ausencia de Dios se expresa mediante imágenes de realidades negativas emparentadas con los sentidos: el oído - el «grito» y el «silencio»-, la vista - la «noche»-y el gusto - la «sed»- ${ }^{6}$.

En el poema «Ecce Homo» el poeta se presenta cara a cara ante Dios para pedirle una explicación:

En calidad de huérfano nonato, y en condición de eterno pordiosero, aquí me tienes, Dios. Soy Blas de Otero, que algunos llaman el mendigo ingrato.

Grima me da vivir, pasar el rato, tanto valdría hacerme prisionero de un sueño. Si es que vivo porque muero, ¿a qué viene ser hombre o garabato?

Escucha cómo estoy, Dios de las ruinas. Hecho un cristo, gritando en el vacío, arrancando, con rabia, las espinas.

¡Piedad para este hombre abierto en frío! ¡Retira, oh Tú, tus manos asembrinas -no sé quién eres tú, siendo Dios Mío!

${ }^{6} \mathrm{El}$ tema de la «sed» recurre en los sonetos «Cara a cara» («vengo, Dios, a decirte -si no a verte- / mi inmensa sed, mi sed de ti: ahogándome»), «Sumida sed» («Te bebía, sentía, y te bebía, / solo, sediento, con palpar de ciego, / hambriento, sí, ¿de quién?, de Dios sería. / Hambre mortal de Dios, hambriento hasta / la saciedad, bebiendo sed, y, luego, / sintiendo, ipor qué, oh Dios!, que eso no basta»). 
El grito del poeta es el de Cristo coronado de espinas. Es su señal de identidad, que es la de un individuo concreto, no anónimo, ni generalizado. Tan concreto, como que es el mismo poeta: «Soy Blas de Otero». Frente a este hombre con nombre y apellido, Dios aparece como un desconocido: «no sé quién eres tú, siendo Dios Mío!». En ese «Soy Blas de Otero» parece resonar el momento en el que Dios revela su nombre a Moisés (cf. Ex 3,14), como resonaba también en unos versos de Cántico espiritual: «Nada soy si no soy el que yo soy, / el que ha salido de Tus manos» ${ }^{7}$. Se trata de una autorrevelación del hombre. Por el contrario Dios se esconde detrás del sufrimiento del que no quiere dar cuentas, detrás de sus «manos asembrinas» (asesinas + siembra). La mano de Dios que pesa implacable sobre el hombre recuerda el texto de Job y de los Salmos:

Ojalá se cumpliera mi petición y Dios me concediera lo que espero: que Dios quisiera aplastarme, que soltara su mano y acabara conmigo (Job 6,8-9)

Tened compasión de mí, compañeros, porque la mano de Dios me ha golpeado (Job 19,21).

Tus flechas se me han clavado, tu mano pesa sobre mí (Sal 38,3).

Retira tu herida de mí perezco a causa de la dureza de tu mano (Sal 39,11).

\section{b) El recurso a la intertextualidad}

La crítica literaria ha señalado frecuentemente el repetido uso de la intertextualidad en Blas de Otero ${ }^{8}$. En sus poemas resuenan los clásicos castellanos (Quevedo, Góngora, Rubén Darío, Juan Ramón Jiménez, Antonio Machado, César Vallejo), los ecos del habla coloquial, la liturgia católica, la espiritualidad juvenil (San Juan de la Cruz) y, por supuesto, la Biblia. A veces mediante juegos de palabras, como en el poema «Y el verso se hizo carne», - donde trata de su idea de la poesía y dice que anda

${ }^{7}$ B. de Otero, Cántico espiritual, p. 132. A. Gil de Zúñiga y Muñoz, Ética y fenomenología religiosa en la poética de Blas de Otero, Valencia, 2011.

${ }^{8}$ Cf. E. Alarcos Llorach, La poesía de Blas de Otero, Salamanca, 1966, pp. 97-99; Á. González, «La intertextualidad en la obra de Blas de Otero», Cuadernos Universitarios 1 (1987) pp. 63-75; L. De Luis, «Los préstamos literarios en la poesía de Blas de Otero», Zurgai 25 (1988) pp. 76-82; L. Montejo Gurruchaga, «El vínculo de Blas de Otero con las Sagradas Escrituras», Zurgai 25 (1988) pp. 102-105; C. Barbosa Torralbo, «Poesía como diálogo. La citación en la obra de Blas de Otero», en A. Vilanova, ed., Actas del X Congreso de la Asociación Internacional de Hispanistas. Barcelona 21-26 de agosto de 1989, Barcelona, 1992, vol. 2, pp. 1645-1654; P. Bellido Navarro, «Trantextualidad en la poesía de Blas de Otero», Investigaciones Semióticas IV, 2 (1992) pp. 563-572; Á. González, «Blas de Otero», en F. Rico - S. Sanz Villanueva, eds., Historia y crítica de la Literatura española VIII/1. Época contemporánea: 1939-1975. Primer suplemento, Barcelona, 1999, pp. 176-178. 
«buscando un verso que se siente / en medio de los hombres»-, o en «Tu reino es de este mundo»-en el que trata del sufrimiento-, o en «Encuesta», en verso libre, lleno de fórmulas litúrgicas, pero en el que expresa su decepción frente a los poetas, la Biblia -que es tan inútil para buscar una respuesta al sufrimiento como la misma guía telefónica- y la espiritualidad aprendida.

Los textos bíblicos están presentes en estos poemas frecuentemente no mediante citas directas, sino mediante imágenes y expresiones que apuntan hacia ellos en un juego intertextual que requiere la colaboración del lector que conoce esos textos. Otero traspone las imágenes bíblicas a su propia experiencia de desarraigo. Podemos apreciar los recursos intertextuales bíblicos, por ejemplo, en un poema como «Muerte en el mar»:

Si caídos al mar, nos agarrasen de los pies y estirasen, tercas, de ellos unas manos no humanas, como aquellos pulpos viscosos que a la piel se asen...

Ah, si morir lo mismo fuese: echasen nuestros cuerpos a Dios, desnudos, bellos, y sus manos, horribles, nuestros cuellos hiñesen sin piedad, y nos ahogasen...

Salva, ¡oh Yavé!, mi muerte de tu muerte. Ancléame en tu mar, no me desames, Amor más que inmortal. Que pueda verte.

Te toqué, oh Luz huidiza, con las manos.

No seas como el agua, y te derrames para siempre, Agua y Sed de los humanos. ${ }^{9}$

El «mar» es protagonista habitual en el imaginario simbólico de Blas de Otero, reminiscencia de sus orígenes bilbaínos ${ }^{10}$. Además del empleo de términos inusuales («ancléame», «desames»), estos versos presentan claras referencias bíblicas a Dios como «mar», como «luz» y como «agua», reforzadas por el sorprendente uso del término «Yavé», que necesariamente nos remite al Dios del Antiguo Testamento:

a) Dios como mar. En las imágenes marinas resuenan los salmos en los que se invoca a Dios que salve el alma / la vida (נפש:) de la muerte (cf. Sal 33,19; 56,14; $89,49 ; 116,8)$, e incluso a la oración de Jonás (cf. Jon 2,3-10). Pero en este po-

\footnotetext{
${ }^{9}$ B. Otero, op. cit., p. 39.

10 «El hombre - o el mundo- es una isla rodeada de un mar amenazador, el de la muerte, el de la nada, y sobre ella hay una bóveda de salvación, el cielo, Dios, hacia la que el hombre -árbol- tiende [...E]n Otero el mar puede ser muerte, puede ser Dios, y otras cosas, aunque todas caracterizadas siempre por lo furioso y vehemente» (E. Alarcos Llorach - C. Blanco Aguinaga, «Lengua y espíritu de Blas de Otero», en Rico -Ynduráin, op. cit., pp. 197-213.202). Alarcos y Blanco analizan en su artículo otros poemas en los que abunda la imaginería marítima y náutica.
} 
ema, Otero expresa con una paradoja de fuerte calado expresivo que la vida no es vida, sino muerte, cuando en lugar de decir «Salva, joh Yavé!, mi vida de la muerte!»-como sería lógico esperar-dice «Salva, ¡oh Yavé!, mi muerte de la muerte», porque la vida es, paradójicamente, una muerte, es saberse abocados a la aniquilación, ser un ser para la muerte.

b) Dios como luz. En las imágenes de la luz reaparecen los milagros de la curación del ciego de Mc 5,22-26 en el que Jesús toca los ojos del ciego y, sobre todo, el ciego de nacimiento de Jn 9. En el «Que pueda verte» resuena el grito del ciego Bartimeo de Mc 10,46-52, y el anhelo del salmista por «ver a Dios» (cf. Sal 27,8; 84,8) e incluso el de Job que por fin recaba de Dios una respuesta y puede verlo (cf. Job 42,5).

c) Dios como agua y sed. Las imágenes de Dios como «agua» y «sed» se hacen eco del Sal 63 («Mi alma está sedienta de ti»), de los pasajes en los que Dios da agua en el desierto (cf. Ex 15,22-27; 17,1-7) y, sobre todo, de los pasajes de la Samaritana (Jn 4,1-42) y de Jesús en la cruz (Jn 19,28-34), en los que Jesús simultáneamente tiene sed y ofrece agua. El oxímoron sed-agua, como vemos, ya está presente en los textos joánicos.

La súplica desesperada a Dios, que parece ser el causante del sufrimiento y, sin embargo, permanece callado, está también presente, por ejemplo, en Sal 102. También Job suplica «¡Ojalá sucediera lo que pido, y Dios me diera lo que espero! ¡Ojalá quisiera Dios aniquilarme, dejarme de su mano y aventarme!» (Job 6,8-9) y «¿Hasta cuándo seguirás vigilándome, sin darme tregua ni para tragar saliva?» (Job 6,19).

\subsection{LA IMAGEN DE DIOS EN LA ETAPA SOCIAL O HISTÓRICA (1955-1964)}

La etapa social o histórica de Blas de Otero viene representada por Pido la paz y la palabra (1955), En castellano (1959), y Que trata de España (1964), en los que el interés se vuelve hacia la situación social e histórica de la España del momento, abandonando los temas más existenciales. En la poesía de la etapa social el hombre ya no aparece como ser débil, arbóreo, angustiado. Ahora surge un hombre nuevo considerado en su dignidad y en su capacidad de transformar el mundo. Por eso puede afirmar: «Creo en el hombre». Dios, Jesucristo, los dogmas, se disuelven ante la crítica despiadada del poeta, como en Poesía con nombres. Esta forma de enfrentar la confesión de fe cristiana es patente en el poema «A la resurrección de Cristo», una curiosa disposición a dos columnas en comentario a los textos evangélicos ${ }^{11}$ :

Juan 20,1 Cuentan que una mañana, aun oscuro, una mujer-María Magdalena,

\footnotetext{
11 B. de Otero, Todos mis sonetos, Madrid, 1977, p. 100.
} 
Mar. 16,6

Luc. 24,2

Mat. 28,3

Juan 20,13

Mat. 28,6

Mat 27,66

Juan 20,14

Juan 20,16

Juan 20,18

Juan 20,25

Juan 20,30

Juan 20,31 dicen- vino a un sepulcro; y vio llena

de susto, atrás la losa, contra el muro,

Y dicen que le dijo un ángel (puro

tal un rayo): ¿Por qué, mujer, tu pena?

Ha resucitado como dijo. En a-

delante nadie sellará seguro.

Esto cuentan. Y dicen más: que Cristo

de pie, habló: María. Y ella: Maestro

(Rabboni). Y luego, a Pedro, a Juan: He visto

al Señor y me ha dicho... Dicen, cuentan.

Pero, yo digo, con Thomás: Si nues-

tro dedo... No sea que los Cuatro mientan.

\section{YEHUDA AMIJAI}

\subsection{VIDA}

Yehuda Amijai (יהודה עמיחי, 1924-2000) nace en Würzburg en 1924, en el seno de una familia ortodoxa judía. Su nombre original era Ludwig Pfeuffer. En la escuela judía que frecuenta aprende la lengua hebrea junto con el alemán. En 1936, ante la creciente hostilidad del régimen nazi, la familia entera emigra a la Palestina bajo el Mandato británico. En la adolescencia rechaza el judaísmo ortodoxo familiar, aunque durante toda su vida conservó las continuas referencias a la tradición judía, los libros de plegarias y la Biblia. Al estallar la Guerra Mundial se enrola en la Brigada Judía del ejército británico. En las bibliotecas móviles del ejército inglés entra en contacto con los poetas ingleses T.S. Eliot, Dylan Thomas, W.H. Auden (con quien mantendrá una amistad) y R.M. Rilke, de quien adopta el uso del lenguaje de aquí y aho$\mathrm{ra}^{12}$. En la Guerra Árabe-Judía de 1948 forma parte del Palmaj. Terminada la guerra estudia literatura y Biblia en la Universidad Hebrea de Jerusalén. Publicó trece libros de poemas, dos novelas, una colección de cuentos, libros para niños y obras de teatro. Sus poemas han sido traducidos a unas cuarenta lenguas ${ }^{13}$. Su trayectoria acadé-

\footnotetext{
12 S. Sandbank, «El paisaje del alma: Rilke, Auden, Amijai [נוף הנפש: רילקה, עודן, עמיחי, Hasifrut 4 (1971) pp. 697-714; R. Alter, «Only a Man», The New Republic, 31 December 2008.

13 Sus libros de poesía son: Ahora y en otros días (עכשיו ובימים אחרים, 1955); A distancia de dos esperanzas (במרחב שתי תקוות, 1958); En el parque (שגינה הציבורית, 1959); Poemas 1948-1962 (1948-1962, que reúne

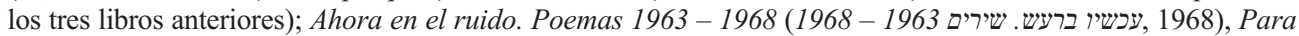

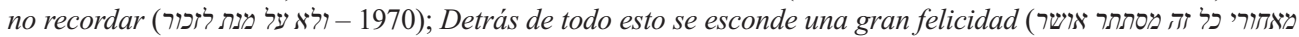

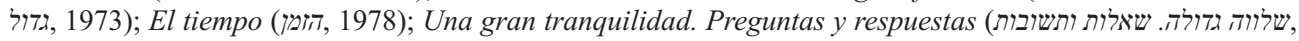

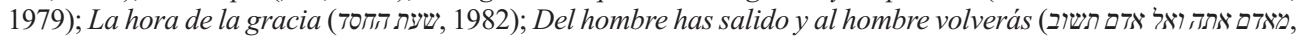

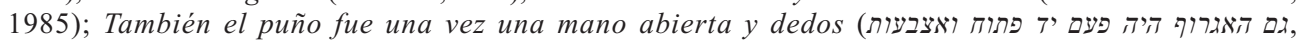


mica está jalonada de cursos en numerosas universidades. Recibió los más prestigiosos galardones de la literatura hebrea ${ }^{14}$. Se le considera el poeta nacional de Israel. Murió en Jerusalén el 22 de septiembre de 2000, víctima del cáncer.

Amijai pertenece al grupo de poetas de los años ' 50 e inicios de los ' 60 que más tarde se llamará Generación del Estado (דור המדינה), que incluye también a Natán Zaj, David Avidán, y Dalia Ravikovich. Esta nueva corriente rompe con la Generación anterior, de tono idealista, que ensalzaba los valores colectivos de la comunidad hebrea en Palestina, las esencias del sionismo, la mística de la lucha por la independencia, etc. La nueva generación de los años ' 50 se enfrenta con la realidad surgida tras la creación del Estado. Aparece una poesía más cercana a la realidad cotidiana y a los problemas personales: el amor, la soledad, los recuerdos de la infancia, la nostalgia por los que ya no están, etc.

\subsection{CARÁCTER DE LA POESÍA DE YEHUDA AMIJAI}

En la poesía de Amijai se da un contraste continuo de la tradición recibida con la experiencia propia. De esa forma, aparecen dos planos contrapuestos: el plano de lo recibido, (el lenguaje bíblico, la imagen del Dios de la Biblia), y el plano de mi realidad concreta, individual, que parece a veces desmentirla. Y la realidad se presenta así, individual, personal, intransferible, la única que no está sujeta a manipulaciones de la ideología dominante. Amijai introduce la realidad cotidiana en una especie de metafisica de lo concreto, que une los elementos de la vida moderna (el humo de la fábrica, las hélices de los aviones, las carreteras, etc.) con las experiencias humanas profundas (el recuerdo de la infancia, la experiencia de la fugacidad del amor, el silencio de los muertos, la cultura destructora de la guerra, etc.). Son experiencias unidas al espectador-narrador, al yo poético que habla en primera persona en casi todos sus poemas, lo que confiere a su poesía un tono especialmente personal y concreto.

Esta experiencia cotidiana, existencial, personal y profunda, es puesta en contacto con el Dios de la Biblia, las promesas, las tradiciones judías, los recuerdos familiares. Amijai deja que las tradiciones judías resuenen en su expresión originaria hebrea, con sus metáforas propias. No crea un lenguaje nuevo para hablar del Dios judío. Lo que es nuevo es el contexto en el que resuena, que es el de la realidad cotidiana del poeta.

En Amijai está presente la Biblia, el peso de la milenaria historia del pueblo judío, los recuerdos de su infancia en el seno de una familia religiosa en Würzburg, de las

1989); Abierto, cerrado, abierto (פתוח סגור פתוח, 1998). Citaré según la edición hebrea de su poesía completa Yehuda Amijai, שירי יהודה עמיחי [Poemas de Yehuda Amijai] I-V, Tel Aviv, 2004, indicando el volumen (en números romanos) y la página. Para las obras de 1955 - 1978 me he servido sobre todo de la traducción de Raquel García Lozano (R. García Lozano, La poesía de Yehuda Amijai, Tesis doctoral en la Universidad Complutense de Madrid, Madrid, 1997), con algunos retoques.

${ }^{14}$ Premio Shlonsky (1961), Premio Brenner (1981), Premio Bialik (1976), Premio de Würzburg de Cultura (Alemania, 1981), Premio Israel (1982), Premio Agnon (1986), Premio Malreaux (Francia, 1994), el Literary Lion Award (Nueva York 1994), Premio de Poesía Bjomson (Noruega 1996). 
oraciones de su padres y de los quehaceres domésticos de la madre, Jerusalén, y, por supuesto Dios, el Dios que alimenta la tradición judía pero que parece ajeno a la aventura de los pueblos y los hombres de hoy; el Dios que existe, pero que existe en su mundo -que no parece el nuestro-y está en sus ocupaciones - que no parecen las nuestras-. En su poesía se plantea de forma radical el contraste entre el Dios de la Biblia y la realidad, entre el amor y la guerra, entre la tradición y la modernidad.

Amijai emplea ciertos recursos estilísticos para transmitir al lector la experiencia de este cuadro de fuertes contrastes:

1. El comienzo en contraste abrupto, que sorprende al lector desde el principio mismo del poema. Se empieza un poema recogiendo un texto tradicional judío-como concediendo la ventaja del primer saque a la posición tradicional- para oponerle en el segundo versículo una refutación sorprendente a este texto ${ }^{15}$.

2. La comparación, que mantiene antiguas metáforas y expresiones pero resituándolas en un contexto nuevo. Por ejemplo, Amijai emplea este recurso para engendrar nuevas imágenes sobre Dios tomadas de la vida moderna. Estas nuevas imágenes sobre Dios siguen un procedimiento ya empleado en la Biblia para expresar la actuación salvadora y eficaz de Dios en Israel y en el mundo ${ }^{16}$. En Amijai, sin embargo, las metáforas sobre Dios expresan también la actividad de Dios en el mundo, pero una actividad que queda más bien al margen de la marcha del mundo, y que casi no influye en é $1^{17}$.

3. La intertextualidad, retomando citas de la Biblia o de la tradición judía, o aludiendo a ellas de forma indirecta ${ }^{18}$. Amijai emplea escenas bíblicas para refe-

${ }^{15}$ Por ejemplo, lo encontramos en «La mano de Dios está en el mundo / como la mano de mi madre en las entrañas de la gallina degollada / la víspera del Shabbat»; o «Jerusalén está fundada sobre cimientos abovedados / de un grito contenido»; o «Dios se compadece de los niños de la guardería / un poco menos de los niños de la escuela»; o «Soy un hombre plantado al borde de la acequia / pero no soy "el hombre dichoso"», etc.

${ }^{16}$ Dios como rey (cf. Sal 84,4; 95,3; 98,6), juez (cf. Gn 18,25; Sal 7,12; Job 9,15), pastor (cf. Is 40,11; Jr 31,10; Ez 34,11-16; Sal 23,1; 80,1), roca (Gn 49,24; Dt 32,4.15.18.30-31; 1 S 2,2; 2 S 22,2-3.32.47; 23,3; Is 8,$14 ; 17,10 ; 26,4 ; 44,8 ; 51,1 ;$ Sal $18,3.32 .47 ; 19,4 ; 28,1 ; 31,4 ; 42,10 ; 62,3.7 ; 71,3 ; 78,35 ; 89,27 ; 92,16 ; 95,1)$, fortaleza (2 S 22,2-3; Sal 18,3; 31,4; 71,3; 94,22), ejercitador militar (Sal 144,1), alfarero (Is 29,16; 41,25; 45,9; 64,7), águila (Dt 32,11), novio (Is 61,10; 62,5), guerrero (Ex 15,3; Is 42,13; So 3,17; 9, 13; Job 16,14; Sal 78,65).

${ }^{17}$ Por ejemplo, «La mano de Dios está en el mundo», que comentamos más adelante, Dios es como una madre con las manos en la gallina degollada preparando el shabbat. En «Viajes del último Benjamín de Tudela»,

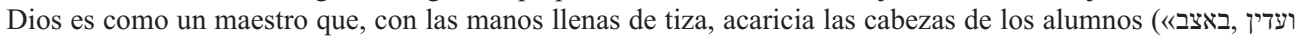

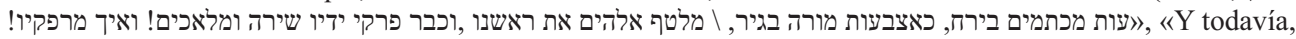
con los dedos manchados de luna, como los dedos de un maestro con tiza, / nos acaricia Dios la cabeza, ;sus muñecas son poesía y ángeles! ¡y cómo lo son sus codos!» [«מסות בנימין מטודילה האחרון», II, pp. 123-124]). En el poema «Y esta es tu alabanza» aparece esta idea de Dios-mecánico ocupado en la reparación del mundo, el

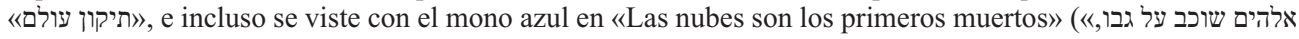
מתחת לתבל, \ממיד עסוק בתיקון \מול תמיד משהו מתקלקל. \רציתי לראות כלו, אך אני רואה \רק את סליון נעליו ואני בוכה. והיא עולמו 》תהילתו", «Dios está tumbado boca arriba bajo el universo, siempre ocupado en la reparación, siempre hay algo

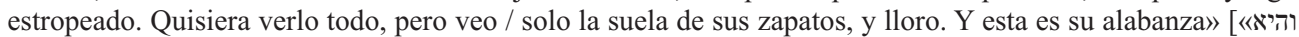

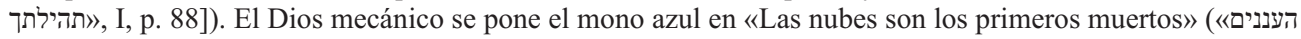
ה הם המתים הראשונים

${ }^{18}$ Cf. C. Kronfeld, «Reading Amichai Reading», Judaism 45 (1996) pp. 311-323; S. Ferrari, «Alcune note su un particolare caso d'intertestualità nella poesia di Yehuda Amichai», Materia Giudaica. Rivista dell'Associazione Italiana per lo Studio del Giudaismo 10 (2005) pp. 375-385. 
rirse poéticamente a realidades absolutamente cotidianas ${ }^{19}$. La poesía de Amijai ha sido catalogada a veces como blasfema o transgresora. Abramson opina que es más bien la ironía que «altera la implicación del texto reconociendo al mismo tiempo su presencia esencial en el pensamiento judío» ${ }^{20}$.

4. El uso del hebreo coloquial junto con expresiones del hebreo clásico, y la introducción de elementos de la vida moderna: el «avión a reacción» (מטוס הסילון), el parque de atracciones «Luna Park» de Tel Aviv (לונה פארק) o la «gasolina» (בנזין).

\subsection{DIOS EN LA POESÍA DE 1948-1962}

a) «Dios se compadece de los niños de la guardería»

El problema de la compasión de Dios aparece ya en «Dios se compadece de los niños de la guardería», de Ahora y en los otros días (1955), uno de los poemas más famosos de Amijai, citado por Isaac Rabin en su conferencia ofrecida al recibir el Premio Nobel de la Paz en $1994^{21}$.

\begin{tabular}{|c|c|}
\hline 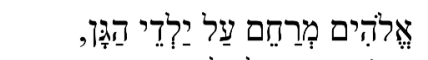 & Dios se compadece de los niños de la guardería, \\
\hline 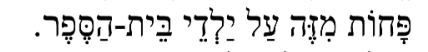 & un poco menos de los niños de la escuela. \\
\hline 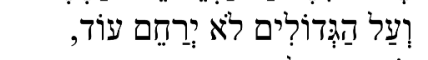 & Pero de los mayores ya no se compadecerá, \\
\hline 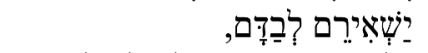 & los dejará solos, \\
\hline 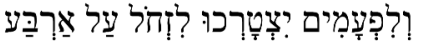 & y a veces tendrán que arrastrase a gatas \\
\hline 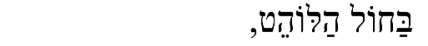 & por las arenas ardientes, \\
\hline 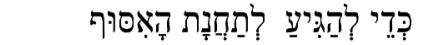 & para llegar al hospital de campaña \\
\hline וֹהֵם שוֹתֶתֵי דָם. & desangrándose. \\
\hline 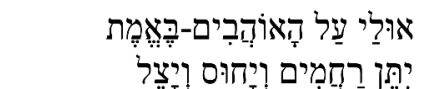 & $\begin{array}{l}\text { Quizá sobre los que se aman de verdad } \\
\text { derramará compasión y les dará refugio }\end{array}$ \\
\hline
\end{tabular}

\footnotetext{
${ }^{19}$ Por ejemplo, la escala de Jacob (Gn 28,11-12) en «Dos poemas sobre las primeras batallas» son los juguetes de una guardería en la que un soldado pasa la noche con su unidad camino del frente (שני שירים על קרבותו רשנות》, I, p. 23). En «Jacob y el ángel» la escena bíblica de Gn 32,23-32 se superpone a la noche de amor cuerpo a cuerpo entre un hombre y una mujer y su separación al salir el sol (《יעקב והמלאך «), I, p. 307). En el

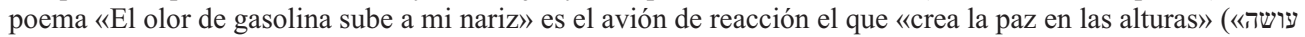
עשלום (שלום במרומיו

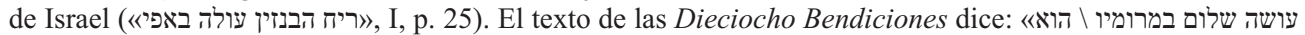
》ע, como en Job 25,2. Cf. N.S. Gold, «A Burning Bush or a Fire of Thorns. Toward a Revisionary Reading of Amichai's Poetry», Prooftexts 14 (1994) pp. 49-69.

20 «The imputation of blasphemy in this poetry is avoided only by its penetrating irony which serves to alter the implication of the text while still acknowledging its essential presence in Jewish thought» (G. Abramson, «Amichai's God»). Cf. A.M. Bejarano Escanilla, «Aproximación a Yehudá Amijai», Sefarad 52 (1992) pp. 3947; Y. Milman, «Sacrilegious Imaginary in Yehuda Amichai's Poetry», AJS Review 20 (1995) pp. 99-121; D. Aberbach, «Religious Metaphor and its Denial in the Poetry of Yehuda Amichai», Judaism. A Quarterly Journal of Jewish Life and Thought, 22 June 2004.

${ }^{21}$ «Dios se compadece de los niños de la guardería» (אלוהים מרחם על ילדי הגן״, I, p. 15).
} 


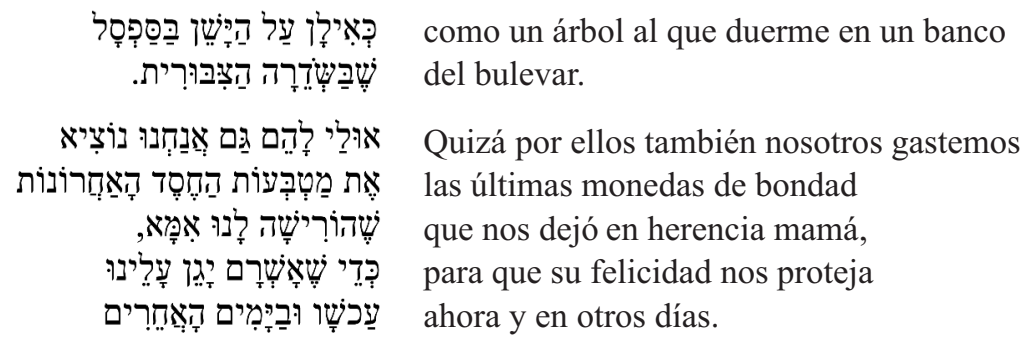

Según Abramson el poema es un comentario burlesco a la interpretación que Rashi hace de Gn 1,1 para quien la creación de la misericordia precedió a la de la justicia ${ }^{22}$. El poema comienza con el contraste abrupto habitual en Amijai: la compasión de Dios hacia los niños de la guardería, pero su progresiva desatención hacia los niños mayores y los adultos. Según la Biblia «el Señor se compadece de quien quiere compadecerse» (Ex 33,19), y «como un padre tiene compasión por sus hijos, se compadece el Señor de los que le temen» (Sal 103,13). Retira su compasión si en Israel reina la maldad (cf. Is 9,$16 ; 13,18 ; 27,11$; Os 2,6) pero tiene compasión sobre Israel para hacerle volver de la deportación (cf. Is 14,1; Jr 33,26; 42,11; Os 2,25). La misericordia de Dios se muestra con los que le temen y con los débiles que confían en él. ¿Por qué entonces Dios, según Amijai, se compadece de los niños pequeños, y no de los soldados caídos?

En la imagen de los que llegan arrastrándose al hospital de campaña desangrándose «a gatas», como los niños pequeños -aunque Dios no se apiada de ellos- vuelven a aflorar recuerdos de soldados muertos, jóvenes con nombres propios, vida y futuro: de su alumno Yonatán Yajil; de la batalla de Asdod, en la que tuvo que cargar con un amigo herido durante varios kilómetros sin saber que ya estaba muerte; de su camarada Diki, y otros muchos ${ }^{23}$.

Solo «los que aman de verdad» (האההבים-באמת)) podrían quizá disfrutar de esa felicidad («רושר) que gozan los niños de la guardería, y quizá sean los únicos herederos de una patria libre y pacificada, simbolizada en la moneda de la herencia ma-

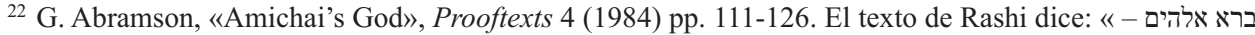
ולא אמר ברא ה', שבתחלה עלה במחשבה לבראתו במדת הדין, ראה שאין העולם מתקיים, הקדים מדת רחמים ושתפה למדת הדין, (היינו דכתיב: ביום עשות ה' אלהים ארץ ושמים ("Creó Dios”, y no dice “Creó el Señor”, porque al principio su pensamiento era crearlo con la medida del Juicio, pero vio que así el mundo no resistiría, por lo que hizo preceder la medida de la Compasión, cooperando con la medida del Juicio, y por eso está escrito: "En el día en que el Señor Dios creó tierra y cielo"». Cf. Génesis Rabbah 12,15; 23,3.

${ }^{23}$ A la experiencia en la batalla de Asdod, a partir de la cual él mismo se considera muerto como su amigo, aparece retratada en el poema «Desde entonces», incluida en Detrás de todo esto se esconde una gran felicidad

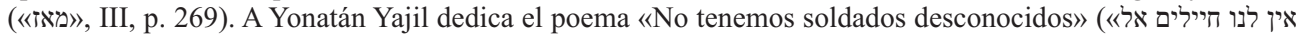
מונים, II, 28). A Diki, muerto en Yad Mordejai, dedicó el relato La muerte de Diki (מותו דיקל דיקים, en la obra colectiva ברוח הנוראה הזאת, Tel Aviv, 1961, pp. 256-263) y una parte de «Elegías por los muertos en la guerra» (קינות על המתים במלחמה", III, pp. 105-110). Cf. S. Ferrari, «Io voglio confondere la Bibbia», ACME. Annali della Facoltà di Lettere e Filosofia dell'Università degli Studi di Milano 55 (2002) pp. 127-188. Sin embargo, como señala Yair Mazor, al tratar el tema de la guerra Amijai es capaz de expresar el sentimiento sin caer en el sentimentalismo «by a deftly calibrated process of restraining emotions, distilling sentiments, dimming the eroding emotional potential, and damming the potentially inordinate effect» (Y. Mazor, «Farewell to Arms and Sentimentalism. Reflections on Israel's Wars in Yehuda Amichai's Poetry», World Literature Today 60/1 [1986] pp. 12-17).
} 
terna. Sobre ellos se extiende la mano protectora de la misericordia de Dios. Esos «amantes de verdad» proporcionan a los demás seres esa misericordia que Dios parece negarles. El fugaz instante del amor, el cuerpo del amante, son frecuentemente para Amijai el único reclamo que ata al ser humano a la vida, la verdadera tierra prometida, en el tiempo de otoño ${ }^{24}$. La fugacidad del amor -el amor de una noche, de un instante, de una semana-y la eternidad de la guerra -las consecuencias de las guerras pasadas, la situación actual, las guerras que se preparan- se entrelazan en la cuerda del tiempo.

Los términos «compasión» (《טים fluyen en la estrofa que trata de la felicidad de los amantes. En la Biblia estos tres términos se refieren fundamentalmente a Dios y llevan la marca de la eternidad ${ }^{25}$. Amijai entrevé que el instante de amor lleva la marca de una cierta eternidad, su felicidad protege «ahora y en otros dí as», verso que da tí tulo a todo el libro.

\section{b) «Dios lleno de compasión»}

En el poema «Dios lleno de compasión», recogido en su libro $A$ distancia de dos esperanzas (1958) ${ }^{26}$ Amijai cuestiona la imagen del Dios misericordioso de la Biblia cuando esa compasión está totalmente oculta en el mundo.

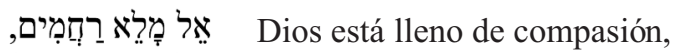

$$
\begin{aligned}
& \text { Sִi Sios no estuviera lleno de compasión } \\
& \text { תhabría compasión en el mundo, y no solo en él. }
\end{aligned}
$$

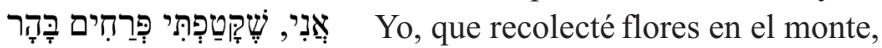

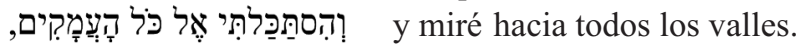

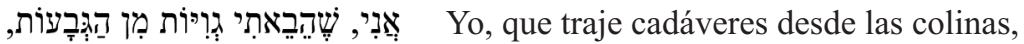

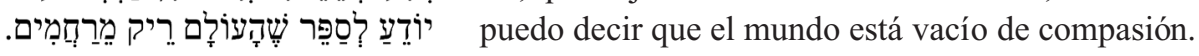

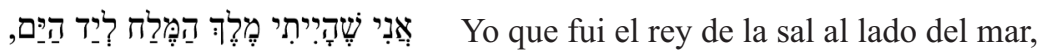

$$
\begin{aligned}
& \text { que permanecí indeciso frente a la ventana, }
\end{aligned}
$$

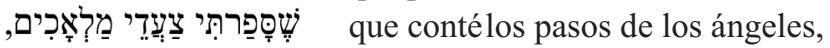

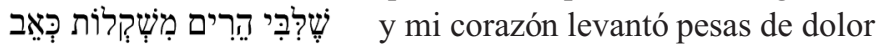

$$
\begin{aligned}
& \text { en terribles campeonatos. }
\end{aligned}
$$

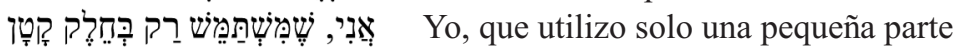

$$
\begin{aligned}
& \text { de las palabras del diccionario. }
\end{aligned}
$$

\footnotetext{
${ }^{24}$ Para los amantes del Cantar de los Cantares, la época del amor está marcada por el despuntar de la primavera

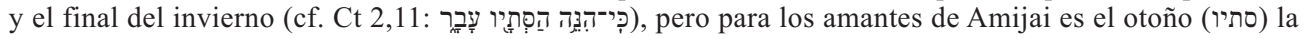
época del amor, que se pasará pronto para dar lugar al invierno de la guerra, a la separación de los amantes,

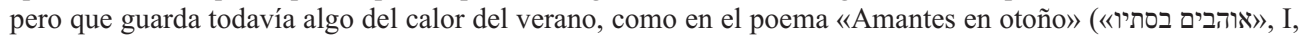
p. 53). El avión de reconocimiento garantiza la paz «a nosotros y a los que se aman en otoño» en el poema «El olor gasolina sube a mi nariz» ("ריח הבנזין עולה באפיו", I, p. 25).

${ }^{25}$ Cf. 1 Cro 16,34; 2 Cro 5,13; 7,3.6; 20,21; Esd 3,11; Sal 18,51; 23,6; 25,6; 40,12; 52,10; 61,8; 100,5; 103,$17 ; 106,1 ; 107,1 ; 117,2 ; 118,1-4.29$; Is 54,8; Jr 33,11.

26 «Dios lleno de compasión» (《ל מלא רחמים», I, p. 86). Cf. N.B. Sokoloff, «On Amichai’s El male rahamim», Prooftexts 4 (1984) pp. 127-140.
} 


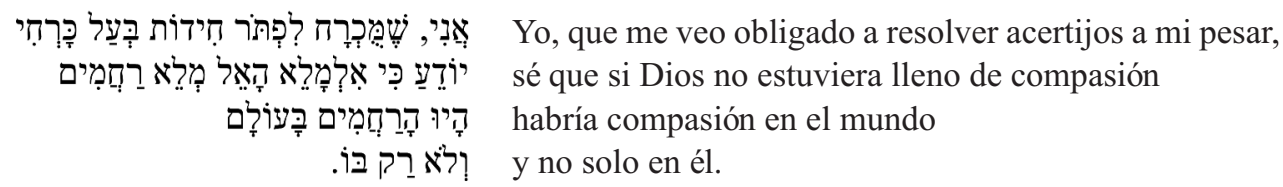

El poema toma su título de la oración fúnebre אל מלא רחמים, Dios lleno de compasión, en la que se encomienda el alma del difunto a las alas protectoras de Dios ${ }^{27}$. Todo el poema está construido desde el principio a modo de fuertes contrastes, que acentúan el abismo entre la afirmación de la tradición judía («Dios está lleno compasión») y la convencida afirmación del poeta («Si Dios no estuviera lleno de compasión / habría compasión en el mundo, y no solo en él»):

- En primer lugar, el ingenioso contraste sonoro o paronomasia en la fórmula 《אלמלא אל מלא רחמים (《Si Dios estuviera lleno de compasión... 》). La secuencia 《אל מלאים (《Dios lleno de....) se convierte en la conjunción condicional negativa 《אלמלאל (《Si no...»). De esta forma el poeta introduce su objeción a la expresión tradicional sobre Dios dentro de esa misma expresión tradicional. La rotundidad de su afirmación queda reafirmada por el hecho de que «אלמלא אל מלא רחמים abre y cierra el poema. La paronomasia o juego de sonidos vuelve a emplearse en

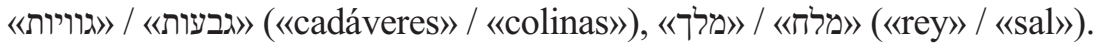

- En segundo lugar, la anáfora «Yo, que...» (《...ש, (אני) que abre cada estrofa, y que hace presente al poeta en primera persona erigido en adversario frente a la postura tradicional como juez, observador, amante, soldado o viajero con sus preguntas, sus dudas, sus recuerdos, sus amores. Su palabra se erige en palabra profética, como la de «un profeta pobre», un «profeta de lo que ha sucedido», consagrado en el amor y en la guerra ${ }^{28}$.

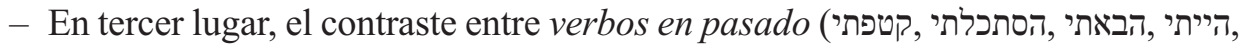

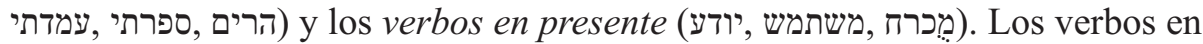
pasado refieren la experiencia del poeta que ha sido testigo de un dolor acu-

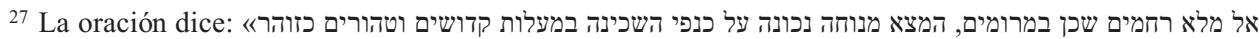

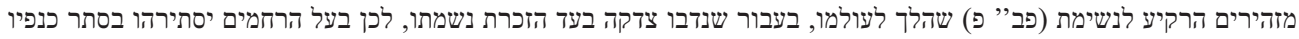
(«ios 1leno de compasión que vives en las alturas, da buen descanso sobre las alas de la Morada en las alturas santas, puras como el resplandor del firmamento y resplandecientes, a N.N. que pasó a su mundo, ya que se ha ofrecido una limosna en recuerdo de su alma. Por tanto, oh Compasivo, escóndelo en lo escondido de tus alas eternamente, y liga su alma a las ligaduras de la vida, que el Señor sea su heredad, y descanse en paz en su lecho. Amén»).

${ }^{28}$ «Yo soy un profeta pobre, como un niño pobre que solo tiene / dos colores. Yo pinto la vida en la guerra / y en el amor, en el ruido y en el silencio» ("Yo soy un profeta pobre» [《ני נביא עניל], V, p. 61). 《Yo soy profeta de lo que sucedió, yo leo el pasado en la palma / de la mano de la mujer que amo, yo soy el hombre del tiempo de las lluvias que cayeron en invierno» («Yo soy profeta de lo que sucedió» [《ני נביאל של משהיה" V, p. 185). «El viento de la madrugada su cabello levantó / y el toque repetitivo del silbato / lo empujo sin pestañear / hacia las filas, con los demás / Y él profetizó arenas que cubren y otoño / y él profetizó paz lejana y otoño» («La consagración como profeta en el campamento militar»] ההקדשה לנביא במחנה צבאי], I, pp. 92-93).
} 
mulado y multiplicado: las «flores» (《פרים)) que son los soldados jóvenes muertos, los cadáveres que llenan las colinas, los mares de lágrimas que lo han convertido en «rey de la sal», las competiciones de pesas de dolor. No es un dolor puntual e individual, sino amontonado y multiplicado. Los verbos en presente, por otro lado, recogen lo que toda esa experiencia del dolor ha producido en el espíritu del poeta: no poder usar más que el lenguaje del sufrimiento («una pequeña parte de las palabras del diccionario»), hacerse preguntas sobre la utilidad de la guerra («solucionar acertijos»).

Al final puede afirmar con rotundidad («Yo sé») que en el mundo no hay compasión, y que la causa de todo ello es que Dios ha reservado toda la compasión para él $\mathrm{y}$, de esta forma, no ha quedado nada para el mundo. Por tanto, la reflexión del poeta, a partir de su experiencia del sufrimiento, se alza contra la imagen del Dios de la Biblia misericordioso y fiel, y cuya bondad se derrama en sus obras, tal como se recoge en Sal 33,5: («La lealtad [70ח] del Señor llena la tierra») y Sal 145,9 («El Señor es bueno con todos, y su compasión [רחמי] está sobre sus obras»). Este mundo escapa a la acción benefactora de la compasión de Dios porque Dios se ha apropiado de toda la compasión.

\section{c) «La mano de Dios está en el mundo»}

El poema «La mano de Dios está en el mundo» se encuentra en la colección $A$ distancia de dos esperanzas (1958) y refleja la aparente despreocupación de Dios ante la marcha real del mundo ${ }^{29}$

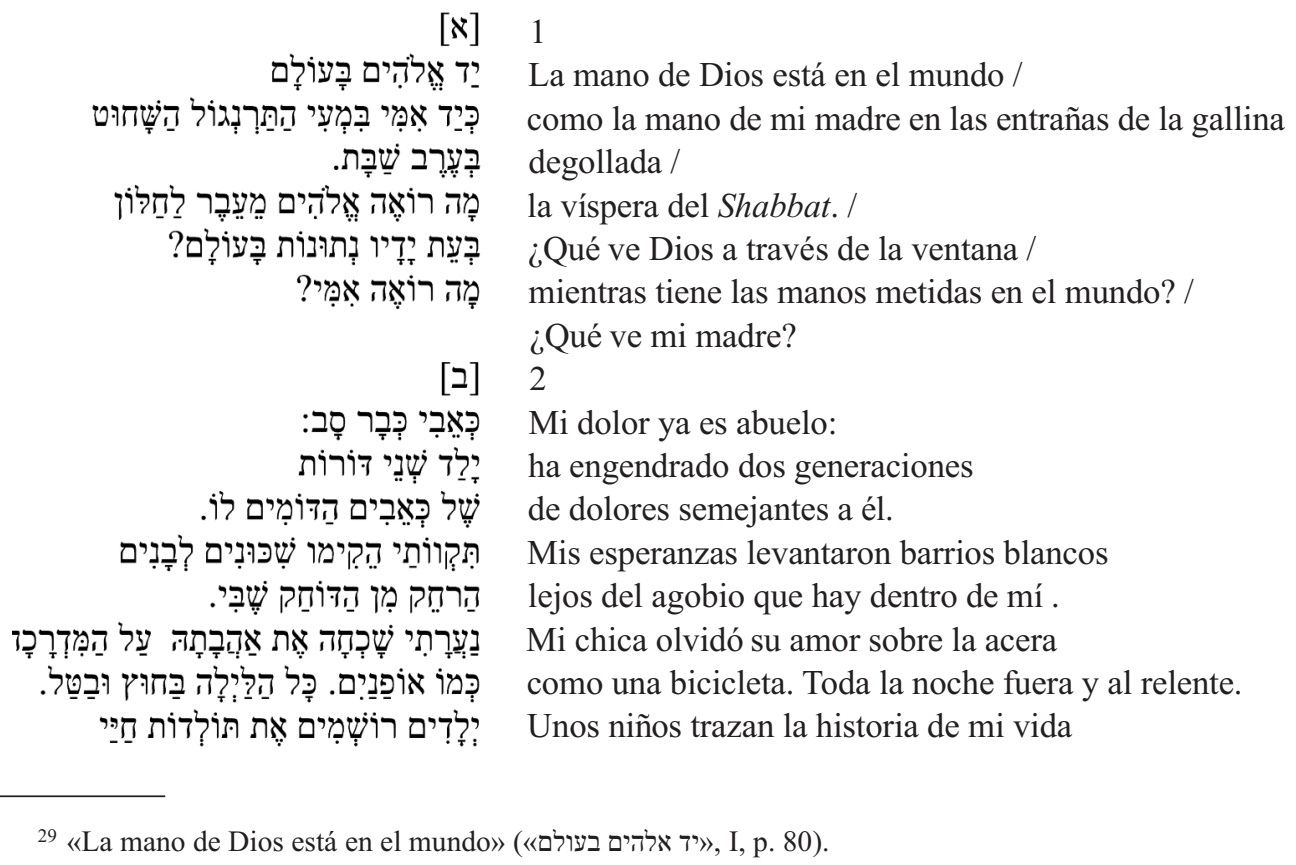

29 «La mano de Dios está en el mundo» (《יד אלהים בעולם)», I, p. 80). 


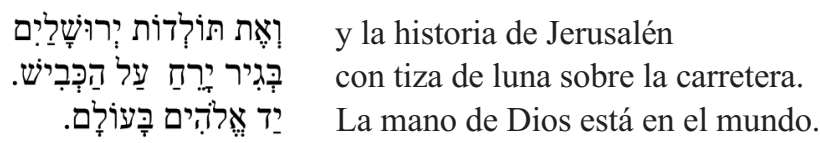

El poema comienza con el contraste abrupto habitual en Amijai, usando una comparación sorprendente: por un lado, el mundo y las entrañas de la gallina degollada; por otro lado, Dios y la madre preparando el Shabbat. La comparación no resulta negativa para la imagen de Dios, ya que su analogatum es una buena madre hacendosa afanándose por preparar bien el Shabbat. La «mano de Dios» aparece en la Biblia mayoritariamente como símbolo del poder de Dios que crea, salva a Israel, impulsa al profeta y castiga a los enemigos ${ }^{30}$. Solo en dos casos la «mano de Dios» es causante de un daño a una persona recta ${ }^{31}$.

Lo que resulta llamativo es que la despreocupación de Dios sobre el mundo es la misma que la de la madre por la salud de la gallina degollada: absolutamente ninguna. Según Amijai, el mundo en manos de Dios es una «gallina degollada». Su quehacer hacia el mundo, la reparación del mundo, el tiqqun olam, es semejante al de una madre cocinera. Por eso se pregunta: ¿en qué pensará Dios? ¿Qué ve Dios desde su ventana? Precisamente el perfil de una mujer que mira por la ventana cambiando de asunto, como su madre, es una de las imágenes de «Viajes del último Benjamín de Tudela». La «ventana» conecta la esfera privada y la esfera pública, dos ámbitos simultáneamente presentes en la poesía de Amijai, como destaca Ed Hirsch ${ }^{32}$. La ventana es metáfora del ser humano, a medio camino entre interior y exterior, ante el que desfilan los acontecimientos, los soldados y los amantes, en el transcurso de la vida ${ }^{33}$.

Mientras tanto, el mundo ha seguido su propia marcha: dolores, esperanzas, amores y recuerdos de la infancia, se han convertido respectivamente en más dolores, en los «barrios blancos» de las nuevas colonias hebreas, en amores olvidados como una bicicleta, en una carretera que lleva lejos de casa. Mientras tanto, «la mano de Dios está en el mundo».

${ }^{30}$ El poder de Yahweh que crea o recrea (cf. Is 41,20; Job 12,9), que salva a Israel (cf. Ex 6,1; 13,3.9.14.16; 32,11 ; Dt 2,15; 3,24; 4,34; 5,12; 6,21; 7,8.19; 9,26; 11,2; 26,8; Jos 4,24; Jc 2,15; 1 S 5,6.9; 7,13; 12,15; Is 19,16; $25,10 ; 59,1 ; 66,14)$, que impulsa al profeta $(2 \operatorname{Re} 3,15 ; \mathrm{Ez} 1,3 ; 3,22 ; 8,1 ; 37,1 ; 40,1)$.

${ }^{31}$ Noemí les confía a sus nueras de que la causa de su desgracia es que «la mano de Yahweh ha caído sobre mí» (Rut 1,13). Job les suplica a sus amigos: «Tened piedad de mí, que la mano de Dios me ha golpeado» (Job 19,21).

32 «One of the central themes of his work has been the way the personal is implicated in the historical, the private impinged upon by the public» (E. Hirsch, «Yehuda Amichai: Poet at the Window», The American Poetry Review, 10/3 [1981] pp. 44-47).

${ }^{33}$ En «La estrella del Jordán es la estrella de los vientos» («III), III, p. 123), la ventana como un hueco vacío es símbolo del hombre, también un hueco vacío. El mismo poeta se considera una ventana,

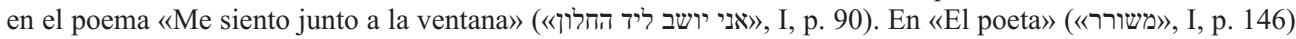

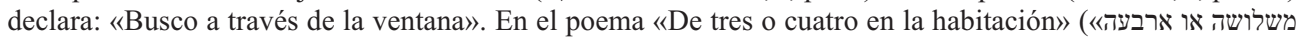
》בחדר I, . p. 97) dice: «De tres o cuatro en la habitación / siempre hay uno junto a la ventana. / Obligado a ver la iniquidad entre las zarzas / y los incendios en las colinas». En el poema «Ibn Gabirol» (《אבן גבירול / dice que «A través de la herida de mi pecho / observa Dios el mundo. / Yo soy la puerta / de su casa». En uno de sus últimos poemas, «Los dioses se sustituyen, las oraciones permanecen siempre» (אלים מתחלפים, התפילות (E) נשארות לעד, V, p. 148) desea un dios-ventana: «Quiero un dios como una ventana, que si la abro / pueda ver el cielo mientras yo mismo me quedo en casa». 


\subsection{DIOS EN LA POESÍA DE 1962-1968: «VIAJES DEL ÚLTIMO BENJAMÍN DE TUDELA»}

Abramson opina que en la poesía de 1962-1968, la que corresponde a Ahora en el ruido (עכשיו ברעש, 1968), Amijai ha cambiado su concepto de Dios: desde una visión antropomórfica de Dios (con ojos, manos y pies, pelo sucio, ropa de obrero) hasta el Dios del Talmud, que no es ya un adversario personal o manipulador del destino humano, y que proporciona una imagen abstracta y ética de Dios, solapando las imágenes de Dios y del padre ${ }^{34}$. Los poemas de «Viajes del último Benjamín de Tudela» ${ }^{35}$, incluidos en Ahora en el ruido (1968), constituyen un revelador relato autobiográfico de Amijai. Amijai emprende un viaje largo; pero, a diferencia del primer Benjamín de Tudela, su viaje es más espiritual que geográfico. En él aparece Dios como el regulador de normas morales y preceptos religiosos de los que el poeta se ha ido desembarazando en su juventud, junto con los ya frecuentes motivos de la infancia y el padre. Para Glenda Abramson es precisamente en este poema donde se encuentra la razón de la centralidad de Dios en la poesía de Amijai ${ }^{36}$.

El poema comienza recordando la advertencia del Deuteronomio ante el posible olvido de Dios «Cuando comas y te hayas saciado... » (Dt 8,10$)$, reconociendo que, efectivamente, se ha olvidado de Dios. La desaparición de Dios del horizonte vital lo expresa como que en un determinado momento de su vida se dio cuenta simplemente de que «Dios no atronaba (רעם); y desde entonces su estruendo fue retrocediendo y se convirtió en un gran silencio (גדולה דממה:), (גדול), quizá en contraste con la espectacular visita de Dios descrita en Is 29,6: («Te visitará el Señor de los ejércitos con el trueno, el terremoto, y un gran ruido» [ברעם וברעש וקול גדול]) y el «gran silencio» que re-

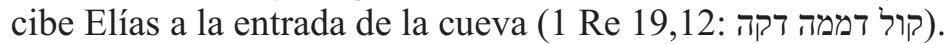

La desilusión por su nueva vida en la Palestina bajo el Mandato británico es semejante al sentimiento de desamparo de Jesús en la cruz al citar el Sal 22,2: «Dios mío, Dios mío, ¿por qué? Me has abandonado. Dios mío, Dios mío. También entonces había que llamarlo dos veces. La segunda llamada / era como una pregunta, por la duda primera: ¿Dios mío? ${ }^{37}$. El sentimiento de abandono va más allá de la situación de inseguridad pública del momento, y se hunde en el vacío existencial-religio-

\footnotetext{
${ }^{34}$ G. Abramson, «Amichai's God», Prooftexts 4 (1984) pp. 111-126; Idem., The Writing of Yehuda Amichai. A Thematic Approach, New York, 1989, pp. 59ss.

35 ספר (מסעות בנימין האחרון מטודילהו" II, pp. 115-158. Se inspira en el relato medieval Libro de los viajes de Benjamín de Tudela (segunda mitad del siglo XII), escrito en hebreo y publicado en Constantinopla (1543) y Ferrara (1556) que recoge los viajes de este personaje desde su Tudela natal por la Corona de Aragón, Provenza, Italia, Grecia, Constantinopla, Palestina, Siria, Bagdad, Egipto entre 1159/1167 y 1172/1173 (cf. C. Roth, «Benjamin (Ben Jonah) of Tudela», en Encyclopedia Judaica, III, Jerusalem, ${ }^{2} 2007$, pp. 362-364). Un viajero del siglo XIX se llamó a sí mismo Benjamín II. Posteriormente, el escritor ruso de origen judío Mendele Mocher Sforim escribió en 1878 Los viajes de Benjamín III (מסעות בנימין השלישי). Amijai se coloca como el último Benjamín de Tudela viajero.

${ }^{36}$ Cf. Abramson, «Amichai’s God».

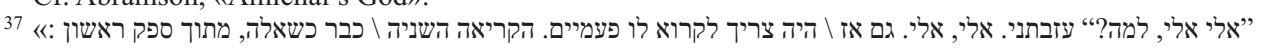
(II, pp. 121-122; cf. Sal 22,1; Mc 15,34; Mt 27,46).
} 
so del poeta que duda de si Dios es verdaderamente «su Dios». Sara Ferrari destaca que en Ahora en el ruido Amijai cite este verso en tres ocasiones, además de en «Viajes del último Benjamín de Tudela»: en «Final de Elul» ("סוף אלול", II, p. 114) y en «Poesías de Akziv» ("שירי אכזיב", II, p. 224). En estas últimas se acusa a Dios precisamente de no haberlo abandonado, es decir, de haberlo comprometido con las prácticas religiosas ${ }^{38}$.

Según Abramson, el Dios de Amijai representa «el sentimiento de necesidad que tiene el poeta de un orden universal y su búsqueda personal de sentido» ${ }^{39}$. A diferencia de la forma en que tratan a Dios otros autores israelíes contemporáneos (Amir Galboa, Natán Zaj, Haim Gury), que «no ven a Dios como un árbitro de su destino personal, ni lo perciben como un componente de su propia identidad», lo propio de Amijai es «su alteración literaria de la naturaleza del Dios de la Biblia hebrea en la noción de Dios también como metáfora, su interiorización de Dios como imagen de ciertas situaciones y estados» ${ }^{40}$.

\subsection{DIOS EN LA ÚLTIMA POESÍA DE AMIJAI}

Abramson opina que en su última poesía, representada por Abierto, cerrado, abierto (סגור, פתוח ,פתוח , 1998), que reúne poemas más largos agrupados a veces en ciclos, el poeta está reevaluando la religión que había abandonado en su juventud, y «sigue un proceso de madurez religiosa: ya no vitupera a la deidad primitiva, antropomórfica que camina sobre la tierra en medio de los hombres; ahora invoca al Señor del Universo adorado por los judíos a lo largo de su diáspora $»^{41}$.

El poema «Los dioses se sustituyen, la oración permanece eternamente» da comienzo a Abierto, cerrado, abierto ${ }^{42}$. El poeta reflexiona ante un trozo de una lápida judía antigua que tiene sobre su mesa y en la que aparece solo una palabra: «Amén». Es el símbolo de la permanencia de la oración frente al paso del tiempo que lo destruye todo, porque «los dioses en el cielo cambian, los dioses se sustituyen, / las oraciones permanecen eternamente» ${ }^{43}$. Es la experiencia del poeta a lo largo de su vida -su visión de Dios ha

\footnotetext{
${ }^{38}$ Cf. S. Ferrari, «Io voglio confondere la Bibbia».

39 "Amichai's God is like no other God in Hebrew poetry in that he represents the poet's own sense of need for universal order and his personal quest for meaning» (G. Abramson, The Writing of Yehuda Amichai, p. 66).

40 «His literary alternation of the nature of God of the Hebrew Bible to the notion also of God as a metaphor, his internalization of God as an image for a number of situations and states of being» (G. Abramson, «Amichai's God», pp. 111-126; Idem., The Writing of Yehuda Amichai, pp. 50-53). Cf. también O. Yeglin, Creator, Are You Listening? Israeli Poets on God and Prayer, Bloomington IN, 2007.

${ }^{41}$ G. Abramson, «Yehuda Amichai», en G. Abramson, ed., Encyclopedia of Modern Jewish Culture, I, London - New York, 2005, p. 29. «His evolutionary view of God seems to follow a process of religious maturing: no longer inveighing against the primitive, anthropomorphic deity who walked on earth among men, he now invokes the Lord of the Universe worshiped by the Jews throughout their dispersal» (G. Abramson, «Amichai's God»; Idem., The Writing of Yehuda Amichai, p. 59).

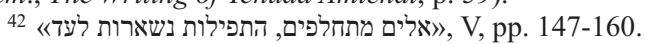

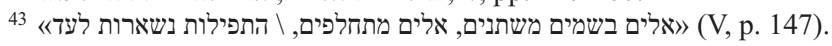


ido cambiando-y lo que percibe en la historia de la humanidad y de las religiones. Amijai sigue recurriendo a las imágenes de la deidad, de los dioses y de Dios cercanas a la realidad cotidiana, como el dios-ventana, el dios-puerta, el Dios-escalera, el Dios-pájaro de playa, el Dios-mago, el Dios-guía turístico. A lo largo de veintisiete poemas de diversa longitud despliega esta idea expresada en el poema 3:

[3]

\begin{tabular}{|c|c|}
\hline 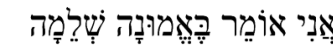 & Digo con fe ciega \\
\hline 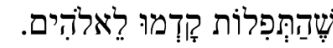 & que las oraciones van por delante de Dios. \\
\hline 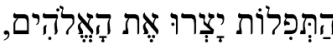 & Las oraciones crearon a Dios, \\
\hline 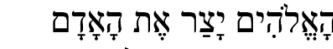 & Dios creó al hombre \\
\hline "ם יוֹצֵר חְִּפְלוֹת & y el hombre crea las oraciones \\
\hline - & ue crean a Dios que cre \\
\hline
\end{tabular}

Amijai afirma la fuerza de la religión en la construcción del ser humano. Son la oraciones, las religiones, quienes han creado a Dios, los dioses, las imágenes de la divinidad que el ser humano se ha ido formando. Pero, a su vez, el ser humano se considera creación de esa divinidad, y esa imagen de Dios creada por la oración penetra hasta el fondo los valores sobre los que el hombre vive, sus decisiones, sus miedos y sus esperanzas. En este sentido, el hombre es la imagen del dios que ha creado con su oración.

El Dios de cada una de las tres religiones aparece representado de esta forma en el poema 8:

El Elos de los cristianos es judío, un poco llorón, /

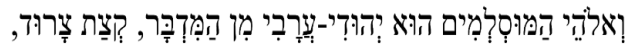

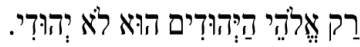

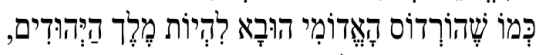

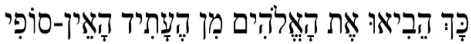

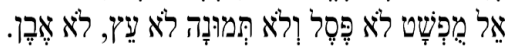
y el Dios de los musulmanes es un judío-árabe del desierto, un poco ronco. /

Solo el Dios de los judíos no es judío. /

Como trajeron a Herodes el idumeo para ser rey de los judíos, / así trajeron a Dios desde el futuro infinito, / un Dios abstracto sin escultura, sin imagen, sin árbol, sin piedra.

Las relaciones entre las tres religiones ya habían aparecido en sus poemas prime$\operatorname{ros}^{44}$. Pero aquí no se trata de las religiones y las creencias, sino de la imagen de Dios que crean las religiones. Para Amijai no es cierto que las tres religiones monoteí stas adoren al mismo Dios. Por el contrario, los creyentes de cada una de estas religiones manifiestan que son imagen de un Dios distinto creado por sus respectivas oracio-

\footnotetext{
44 «He estado en Jerusalén y en Roma. Quizá algún día esté en La Meca» («Y esta es tu alabanza» [«יאי קתהילתך, I, p. 88]). «Estoy cansado y maldigo a las tres famosas religiones / que no me dejan dormir por la noche, con campanas / y plegarias, con cuernos y molestos poemas penitenciales» («Final de Elul» [《לול אלוף》, II, p. 114]).
} 
nes. Y cada uno de esos dioses crea un tipo distinto de hombre. El problema no es ya ahora si Dios interviene en la reparación del mundo, el tiqqun olam, y cómo le afectan los sufrimientos del mundo. Efectivamente, Dios interviene, pero no como el Dios tapa-agujeros, sino como el que está en el origen de las cosmovisiones que habitan los seres humanos.

¿Cómo es el Dios judío? ¿Cómo afecta al ser judío la peculiar condición de Israel como pueblo elegido? ¿Qué significa la Torá no solo para el pueblo judío, sino también para ese Dios que es producto de la oración judía y que crea al hombre y la mujer judíos? Amijai lo expresa en estos tres poemas que combinan resonancias rabínicas con el humor y la ironía:

[5]

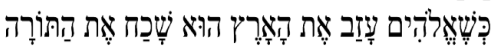

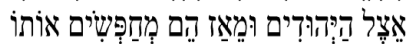

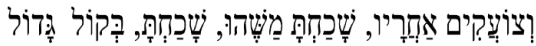

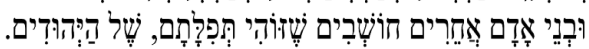

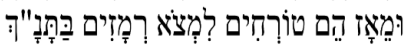

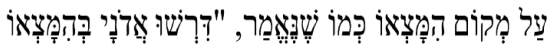

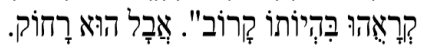

[9]

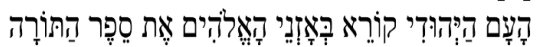

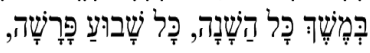

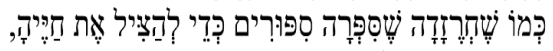

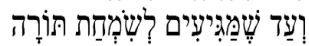

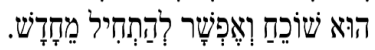

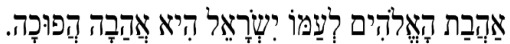

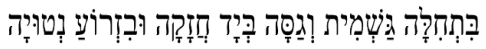

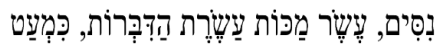

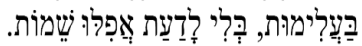

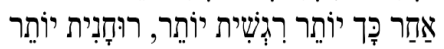

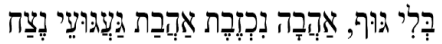

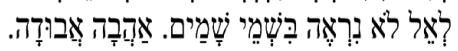

\section{Cuando Dios dejó la tierra olvidó la Torá /} en casa de los judíos, y desde entonces ellos lo buscan /

y gritan detrás de él: «¡Has olvidado algo, has olvidado!», a grandes voces, /

y los otros creen que esta es su oración, la de los judíos. /

$\mathrm{Y}$ desde entonces se esfuerzan por encontrar señales en la Biblia /

sobre el lugar donde se encuentra, porque está escrito: «Buscad al Señor mientras se le encuentra, / invocadlo mientras está cerca». Pero él está lejos.

El pueblo judío recita a Dios el libro de la Torá / durante todo el año, cada semana una parashá, / como Sherezade, que contaba historias para salvar su vida, / y hasta que llegan al simjat Torá, él olvida y se puede empezar de nuevo.

El amor de Dios por su pueblo Israel es un amor al revés./

$\mathrm{Al}$ principio material y grosero, con mano fuerte y brazo extendido /,

milagros, las diez plagas, los diez mandamientos, casi /

con violencia, sin conocer ni siquiera los nombres./

Después, más emocional, más espiritual, /

sin cuerpo, un amor no correspondido, un amor con nostalgia eterna /

de un Dios invisible en los cielos. Un amor perdido. 


\section{CONCLUSIÓN}

Otero y Amijai echan mano en su poesía de expresiones e imágenes bíblicas para pintar a ese Dios y para hacer hablar al hombre que reclama su respuesta. Ambos poetas comenzaron su trayectoria biográfica anclados en sus respectivas tradiciones religiosas: Blas de Otero se educa en un colegio jesuita y en su juventud milita en organizaciones católicas, y Yehuda Amijai nace en Alemania en el seno de una familia judía ortodoxa. Su poesía refleja la huella de su vivencia religiosa familiar tradicional. Son la muestra de que el acceso al Dios de la Biblia está siempre condicionado por una tradición religiosa en la que el poeta vive. Es la prueba de la paradoja expresada por Amijai en su poema «Los dioses se sustituyen, las oraciones permanecen para siempre».

Ambos se alejan de esa fe tradicional. La poesía de Blas de Otero y Yehuda Amijai se podría calificar como poesía heterodoxa, no ajustada a los moldes tradicionales; una poesía deconstruccionista y demoledora de la imagen del Dios de la Biblia. De todas formas, en el fondo de sus escritos se atisba un reclamo por construir una imagen verdadera de Dios, porque el Dios de la Biblia, en el fondo, no se deja encasillar en fórmulas. El lenguaje bíblico no esconde imágenes de Dios que podrían parecer heterodoxas ${ }^{45}$. En el fondo, las imágenes de Dios de Otero y Amijai no están tan lejanas de algunas imágenes bíblicas, y continúan en cierto modo sus metáforas.

Otero y Amijai nos retan a dar el paso de un Dios sabido, un Dios domesticado, conocido y predicado de memoria, a un Dios sorprendente, Totalmente-Otro, que no permite ser representado por imágenes de lo que hay aquí abajo (cf. Ex 20,3-4). Un Dios que no está al servicio del hombre, que, aunque hable en lenguaje humano y su imagen esté presente en el hombre, sin embargo rompe los moldes en que el hombre le encasilla. Un Dios que no responde cuando él se lo pide, sino que es libre de escoger el modo y el momento para responder. En el fondo, ¿no es este el Dios de la Biblia, un Dios que no se deja encasillar?

Junto a los rasgos comunes, el contacto con las obras de Otero y Amijai nos hace descubrir también las grandes diferencias entre estos dos poetas:

La poesía de Blas de Otero es desgarrada, apasionada, provocadora. «Escribo como escupo. Contra el suelo / ... y contra el cielo», declaraba en Ancia. Es un grito a Dios que se convierte en un grito frente al vacío. No se conforma con el silencio de Dios y vuelve a la carga una y otra vez. Busca provocar un shock en el lector, removerlo de sus comodidades y dejarlo en el abismo de soledad ante la muerte que el poeta mismo experimenta. Se dirige a Dios directamente, lo interpela, le grita. El problema del Dios de Blas de Otero es su silencio a los reclamos del hombre mortal. Dámaso Alonso comenta que «toda la poesía de Blas de Otero es una desesperada carrera hacia Dios, un buscar en soledad» ${ }^{46}$. Manuel José Rodríguez considera que, en Blas de Otero, «el

\footnotetext{
45 El mismo san Agustín, por ejemplo, comenta a propósito del Sal, 78,65: «Mi Señor se despertó como de un sueño, como guerrero aturdido por el vino»: «Nullus hoc de Deo dicere auderet, nisi Spiritus eius» («Nadie que no fuera su Espíritu se atrevería a decir esto de Dios», San Agustín, Enarrationes in Psalmos, 77, p. 39, advertido por Ravasi [G. Ravasi, Il libro dei Salmi, I, Bologna, 1986, pp. 32-34]).

${ }^{46}$ D. Alonso, «Poesía arraigada y poesía desarraigada», p. 353.
} 
concepto de Dios que emerge, a pesar de todo, es de raigambre místico-cristiana», arraigado en la actitud del poeta que reclama, eso sí, «un Dios más humano, más como el hombre», y grita -recogiendo un verso de Ángel fieramente humano,- «un deseo de Dios enternecido» ${ }^{47}$. Para Alarcos Llorach el Dios de Ancia «parece a veces el terrible del Antiguo Testamento; para nada aparece el aspecto humano de Dios encarnado en Cristo, al contrario que en otros poetas de su promoción, en los cuales la inspiración religiosa es ternura, caridad» ${ }^{48}$. Gil de Zúñiga ha rebatido recientemente esta opinión de Llorach, y propone que en Blas de Otero se encuentra «un nuevo modo de entender la trascendencia y su consiguiente religación» que surge tras el contacto con el marxismo en los años '50, en la línea del «ateísmo en el cristianismo» de Ernst Bloch, que reclama un cristianismo comprometido en la lucha por la justicia ${ }^{49}$.

La poesía de Amijai, por el contrario, nos aparece mucho más serena. Amijai es un viajero que recorre los lugares de la Tierra Prometida, de Europa y América del Norte, de su Würzburg natal, de la tradición judía y de la ciudad moderna disfrutando de su belleza y ofreciendo su visión crítica. Dios tiene algo que ver con esos lugares; lo que ocurre es que es como un mecánico, y está tan entretenido con los deberes que le ha impuesto la tradición judía, el tiqqun olam, que no tiene tiempo para ocuparse de los humanos. Por eso Amijai no se molesta ni siquiera con invocarlo o con dirigirse directamente a él, porque sabe de antemano que es inútil. Para Amijai la supervivencia del pueblo judío a lo largo de la historia no ha sido obra del Dios «de mano fuerte y brazo extendido» de la Biblia, que está ocupado en otros menesteres, sino de la permanencia de la tradición judía que abarca la Biblia, el Talmud, la oraciones de la sinagoga, los poetas hebreos medievales, los intelectuales de la Haskalá e incluso el proyecto sionista. Todos estos factores han cohesionado una identidad judía a lo largo de los siglos. En todos ellos está presente el Dios de la Biblia, pero la salvación del pueblo judío no ha dependido del «Dios de la tradición», sino de la «tradición sobre Dios». Como reconoce Glenda Abramson, Amijai «ha creado una forma única de lenguaje poético y, de hecho, una nueva exégesis», ya que «no solo demuestra un conocimiento de las fuentes que conlleva su educación marcadamente ortodoxa, sino también una conciencia instintiva de que estas pueden ser valiosas para su vida y la de su generación ${ }^{50}$.

Los poetas dan voz al hombre de cada tiempo. Otero y Amijai en cierto modo han dado voz a las inquietudes de nuestra época, que encuentra una dificultad especial para acceder al Dios de la Biblia y rechaza las visiones de Dios que ignoran sus problemas existenciales. Por otro lado este reclamo no está lejos del lenguaje bíblico, que habla de Dios no en lenguaje abstracto, sino cercano a las hambres y preguntas del hombre.

\footnotetext{
${ }^{47}$ M.J. Rodríguez, Dios en la poesía española de posguerra, Pamplona, 1977, p. 104.

${ }^{48}$ E. Alarcos Llorach, op. cit., p.37. Alarcos Llorach solo ve alusiones a Jesucristo en algunos poemas de Cántico espiritual.

${ }^{49}$ A. Gil de Zúñiga y Muñoz, El Dios de Blas de Otero, Tesis doctoral UNED, Madrid, 2010, p. 336. Manuel José Rodríguez también destaca la dimensión ética de la poesía de Otero como respuesta al derrumbe interior del hombre y a la exigencia de una fe auténtica (cf. M.J. Rodríguez, op. cit., pp. 265-271).

${ }^{50}$ G. Abramson, «Amichai's God».
} 